\title{
Tracers of uplift and subsidence in the Cape Verde Archipelago
}

\author{
electronic supplement \\ Ramalho*, R.; Helffrich, G.; Schmidt, D.; Vance, D.
}

Department of Earth Sciences, University of Bristol, Wills Memorial Building Bristol, BS8 1RJ, UK

${ }^{*}$ Corresponding author: ric.ramalho@bristol.ac.uk.

\section{Introduction}

This an electronic supplement of the paper "Tracers of uplift and subsidence in the Cape Verde Archipelago". The objective of this supplement is to provide more detailed information on the volcanostratigraphy of some of the Cape Verde islands mentioned in the main text, and a detailed description of key palaeo-markers of relative sea-level height used to track the history of vertical movements affecting those islands.

\section{Palaeo-markers of sea-level in the Cape Verde islands}

\section{$2.1 \quad$ Sal}

Sal's volcanostratigraphy comprises (Silva et al. 1990; Torres et al. 2002a): Ancient Eruptive Complex; Principal Eruptive Formation; Ponta do Altar-Baleia Complex; Conglomerate Brec- 
cia; Ribeira da Fragata Formation; Serra Negra Eruptive Formation; Monte Grande-Pedra Lume Formation; and Quaternary Sediments (see Figure S1, and Table 1 in the main text).

\subsubsection{The Ancient Eruptive Complex}

The Ancient Eruptive Complex constitutes the basement unit and is profoundly eroded and weathered. It occurs mainly in the central part of the island where it reaches the maximum elevation of $\sim 60 \mathrm{~m}$ asl. Silva et al. (1990) and Torres et al. (2002b) describe the Ancient Eruptive Complex as a complex sequence of formations mostly comprising hydrovolcanic products of effusive and explosive nature. The whole unit is intensively intruded by dykes - up to $95 \%$ of the outcropping area - and small plutonic bodies, a condition that in conjunction with the advanced state of weathering exhibited by its products is an obstacle for solid event reconstructions.

The oldest products seem to comprise weathered basaltic pillow-lavas, pillow-breccias and hyaloclastites (Torres et al. 2002a) probably extruded in the Late Oligocene as the $25.6 \pm 2.2 \mathrm{Ma}$ K-Ar age suggests (Torres et al. 2002b). Volcanic breccias of trachytic, trachyphonolitic and basaltic nature occur in association with the previous lithologies (Silva et al. 1990; Torres et al. 2002a), also exhibiting a typical hydroclastic texture (often with glassy matrix) and supporting a submarine environment for the origin of the Ancient Eruptive Complex (Torres et al. 2002a).

In their study, (Torres et al. 2002a) state that the final effusions of the Ancient Eruptive Complex correspond to 'small and scarce' fissural subaerial flows with plugs, dykes and flows of phonolites. These outcrops, though, probably belong to the younger Principal Eruptive Formation, due to their apparent discordance with the submarine volcanic products attributed to the Ancient Eruptive Complex. The complexity and weathering of the Ancient Eruptive Complex unfortunately prevent conclusive event reconstructions based on field observations.

Silva et al. (1990) noted the presence of small outcrops of dolomitic limestone apparently within the ancient submarine lavas, near Espargos. These sediments occur in a discontinuous 


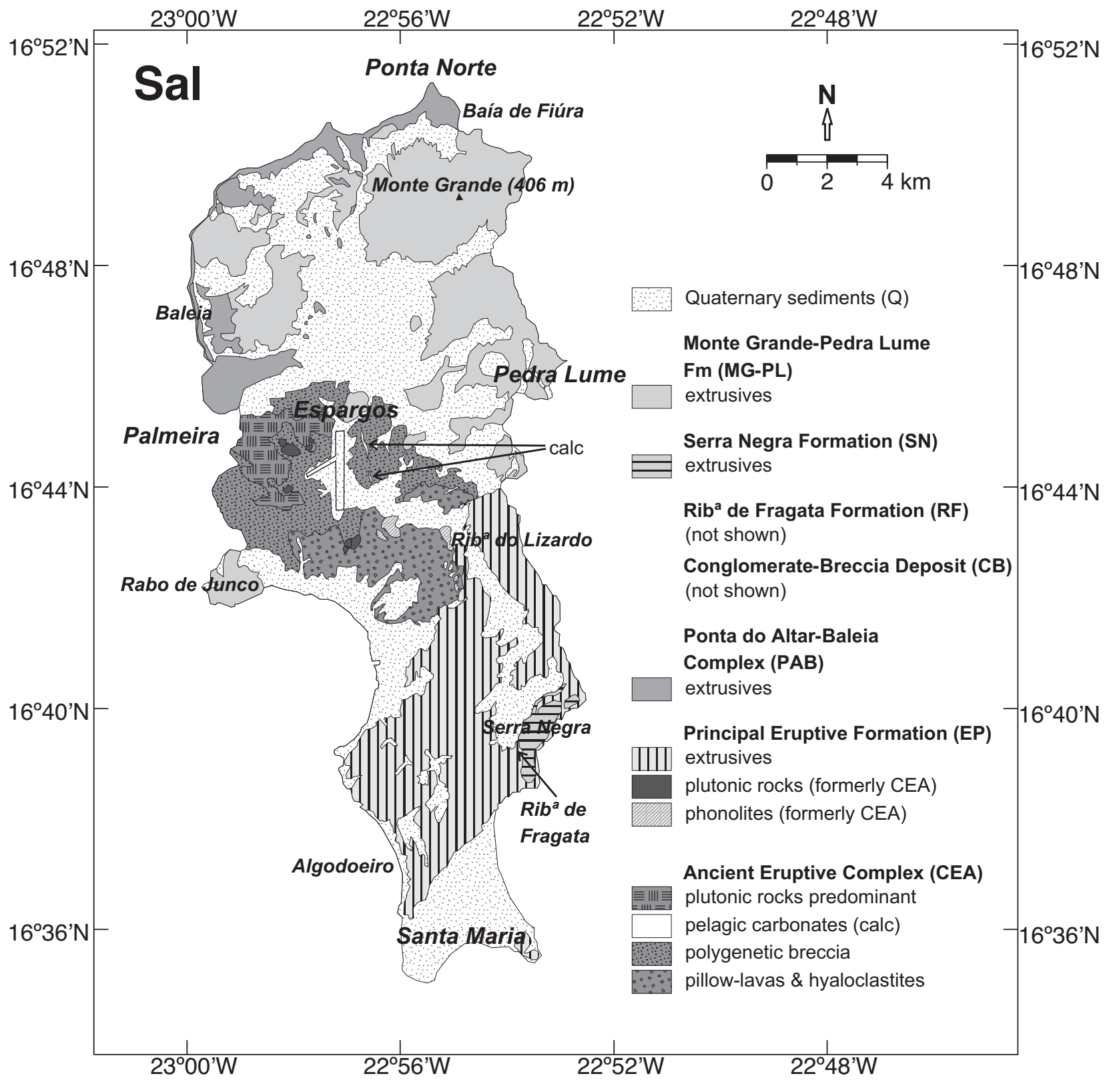

Figure S1: Geological map of Sal, modified from Silva et al. (1990) and Holm et al. (2008). 
outcrop extending over $1600 \mathrm{~m}$ running N-S to NNW-SSE, exhibiting a maximum thickness of about $1.5 \mathrm{~m}$ and dipping between $30^{\circ}$ to $45^{\circ}$ to ENE (Ubaldo et al. 1991; Torres et al. 2002a). The outcrops are presently found at elevations ranging from 40 to $50 \mathrm{~m}$ above sea-level (asl). The limestones are micritic mudstones with abundant microfossils. The attribution of an age by biostratigraphy is not simple. A previous study by Ubaldo et al. (1991) revealed a planktonic fauna attributed to the Mid Miocene, with reworked Oligocene-Miocene material. According with these authors, faunal preservation is poor and is dominated by globigerinoides, with minor quantities of globigerinas and globoquadrinas. The presence of Orbulina universa is mentioned by Ubaldo et al. (1991) which would place a lower age constraint of 14.7 Ma on these sediments (Berggren et al. 1995). Our own study revealed a faunal association dominated by unkeeled planktic foraminifera where O. universa seems to be absent (Haydon Bailey, person. comm. 2009) This association would suggest instead a Early Miocene age for these sediments (21.5-16.4 Ma). In agreement, the lack of keeled forms and the absence of Fohsella spp. - so abundant in tropical and subtropical Mid Miocene associations - seems to be another indicator of Early Miocene age. However, a single specimen of Praeorbulina sicana was found in one of the thin sections made for this study. This species is restricted to Zones N8-N9 (lower part) and would restrict the age of this material to a Langhian age (14.5-17 Ma) (Ogg et al. 2008). Since the attribution of an age based in a single occurrence is not solid enough, we therefore use a wider age interval between 21.5 and 14.5 Ma, but the possibility for this material to be Langhian with reworked Early Miocene faunas should not be discarded. Notwithstanding, the spatial coexistence and the age overlap between pelagic limestones, apparently interbedded within the Ancient Eruptive Complex sequence, with submarine and subaerial lava flows from the Principal Eruptive Eruption poses a geological problem that is still unresolved. 


\subsubsection{The Principal Eruptive Formation and the Ponta do Altar-Baleia Complex}

The Principal Eruptive Formation lies unconformably over the Ancient Eruptive Complex and comprises mainly submarine and subaerial lavas (lower series) and subaerial lavas (upper series), possibly extruded around $16 \mathrm{Ma}$ (lower series) and 9-10 Ma (upper series) (Torres et al. 2002a). Holm et al. (2008) proposed an age range of 16 to $14 \mathrm{Ma}$ for the lower series, considering the upper series to be part of the Ponta do Altar-Baleia Complex. However, it is more likely that the Principal Eruptive Formation and the Ponta do Altar-Baleia Complex were extruded during the same event, in a wider period between 16 and 9 Ma. This possibility is suggested by the island's volcanic structure and the apparently synchronous available geochronological data (Torres et al. 2002a; Holm et al. 2008), a possibility already admitted by Torres et al. (2002a). Thus, The Principal Eruptive Formation and the Ponta do Altar-Baleia Complex seem to be the result of the main shield-building stage of the island's evolutionary history.

The Principal Eruptive Formation submarine flows can be found in the lower part of the sequence, probably constituting the oldest exposed rocks of this unit. They can be found exclusively in a small area in the central-eastern part of the island (between Ribeira do Lizardo and Morro da Terra Branca). In this area the submarine sequence consists of a pile of pillow and lobate lavas, embedded in hyaloclastites, all very weathered. It is possible in places to observe the passage zone between subaerial and submarine morphologies, suggesting a contemporaneous water level at $\sim 50 \mathrm{~m}$ asl. The precise age of these lavas is still unknown because the geochronological data published so far (Torres et al. 2002a; Holm et al. 2008) was determined in the subaerial lavas found several kilometers to the south. The fact that the upper sequence of the Principal Eruptive Formation is presently found as low as the modern sea-level suggests that the relative sea-level height during the age range of its products was below the present level.

The Ponta do Altar-Baleia Complex, comprises from the base to the top: subaerial and 
submarine flows; shallow marine sediments; subaerial flows (and its vents) (Torres et al. 2002a). According to Torres et al. (2002a) this unit extruded in the north and northwest part of the island, between Baía de Fiúra and Palmeira. The basal subaerial lavas presently crop out from 0 to $27 \mathrm{~m}$ asl and are covered by submarine flows. These were once extensive (but not very thick) and have been eroded to the point that only isolated outcrops can be found over the basal subaerial flow (Torres et al. 2002a). These isolated outcrops can be found up to $2 \mathrm{~km}$ inland, up to $32 \mathrm{~m}$ asl. Thin (normally $<1 \mathrm{~m}$ ) shallow marine carbonates can be found above the previous units (and below the later subaerial flows), exposed only on the coast. They are probably contemporaneous with the erosional period that dismantled the submarine flows. The sediments comprise mainly fossiliferous calcarenites, with lenses of conglomerates, sands and silts (Torres et al. 2002a). Their fossils include small corals, gastropods, bivalves and echinoid spicules, compatible with the very shallow depths typical of beach deposits. Later thin subaerial flows partially covered the sequence, sometimes surrounding the higher outcrops of submarine lavas (Torres et al. 2002a). The Ponta do Altar-Baleia sequence suggests contemporaneous small scale variations in the relative sea-level height, at least between 0 and $32 \mathrm{~m}$ asl.

\subsubsection{Intercalated sediments}

The Conglomerate Breccia and the Fragata Formation corresponds to the sedimentary products of a subsequent period of volcanic quiescence and erosion. The first comprises mud and debris flow deposits and the latter is formed of fossiliferous shallow marine carbonates (Torres et al. 2002a).

The Fragata Formation lies unconformably over the Principal Eruptive Formation subaerial flows, and is covered by the submarine lavas of the Serra Negra Formation (Torres et al. 2002a). This carbonate constitutes a very regular horizon not exceeding $2 \mathrm{~m}$ of thickness, and was deposited in a contemporaneous wave-cut surface presently at $\sim 50 \mathrm{~m}$ asl. These sediments exhibit a conglomeratic basal layer overlain by a compact calcarenite bed. The conglomerate 
is poorly sorted, graded, with large sub-rounded to well-rounded terrigenous clasts supported by a calcarenitic matrix. Its fossil association includes echinoids, gastropods, bivalves and rare isolated corals. The uppermost layer is a $50 \mathrm{~cm}$ thick graded compact calcarenite, exhibiting a grainstone/floatstone texture, and rich in rhodoliths, gastropods and bivalves. These features suggest that the sediments were originally formed in a high energy environment of very shallow depth, but the environment changed to calmer and deeper waters (as suggested by the presence of well articulated rhodoliths and the increase of finer material). The observed transition might be the result of a small relative sea-level rise compatible with the culmination of a highstand. Torres et al. (2002a) attributed an Late Miocene age to these deposits, based on the fossil association, and the age of the overlying submarine volcanic sequence.

\subsubsection{The Serra Negra post-erosional volcanic sequence}

The Serra Negra Formation is a volcanic sequence that corresponds to an eroded lava delta whose source vents are no longer distinguishable. The sequence comprise NW dipping foresets of hyaloclastite breccia, with clusters of pillow-lavas, covered by flat-lying subaerial lavas not exceeding a total thickness of 10 to $15 \mathrm{~m}$. The passage zone is clearly visible and regularly crop out at $\sim 90 \mathrm{~m}$ asl, constituting a solid indication of contemporaneous sea-level height. The subaerial lavas seem to have been extruded around 5.5 Ma (Torres et al. 2002a; Holm et al. 2008), so we assume the submarine lavas to be contemporaneous. The Serra Negra Formation lies conformably over the Ribeira de Fragata Formation.

\subsubsection{Recent sediments and last post-erosional volcanic activity}

On the west bank of Ribeira da Fragata, near its source, a marine conglomerate crops out at $70 \mathrm{~m}$ asl, above the hyaloclastites of Serra Negra Formation and below fossil sand dunes. These sediments were considered Quaternary by Silva et al. (1990) but later Zazo et al. (2007) suggested a broader Plio-Pleistocene age. Its presence suggests a probable contemporaneous 
sea-level height close to $75-80 \mathrm{~m}$ asl.

The final eruptive stage to occur in Sal was designated Monte Grande-Pedra Lume Formation by Silva et al. (1990) and was probably extruded between 0.6 and 1 Ma bp (Torres et al. 2002a; Holm et al. 2008). The unit comprises a series of isolated strombolian-hawaiian cones with exclusively subaerial products. The phreato-magmatic structure of Pedra Lume is also included in this unit. The products of this stage are only found in the central/northern part of the island and crop out down to the present sea-level.

A series of Quaternary marine terraces was noted by Bebiano (1932); Lecointre (1963); Serralheiro (1968), and later mapped by Silva et al. (1990). These terraces a distinctive features of Sal's landscape because they cover large areas of the island with a remarkably flat morphology. For a very detailed study refer to Zazo et al. (2007), who identified and described 16 different terrace levels from 1 to $60 \mathrm{~m}$ asl. However, these authors do not mention of the $100 \mathrm{~m}$ level, on top of Serra Negra, previously identified by Silva et al. (1990). Our study reveals these outcrops to be $<30 \mathrm{~cm}$ thick compact limestones, weathered, partially recrystallized, and very poor in macro-fossils. In thin section these rocks show an oosparite boundstone texture with poorly sorted, graded, well-rounded grains with several generations of overgrowth of the grains, resulting in typical oncoidal structures - features indicative of a high energy shallow marine environment. The nature of the sediments, together with the regular flat-lying morphology of the top surface of Serra Negra where the sediments lye, suggests the existence of a wave-cut surface and terrace in this place. Thus, in our view, the $100 \mathrm{~m}$ terrace reflects a contemporaneous sea-level position (the highest Plio-Pleistocene terrace in Sal) and should be included in freeboard reconstructions. We propose that this terrace is older than $1 \mathrm{Ma}$ because this is the oldest age obtained for the Monte Grande-Pedra Lume subaerial lavas, found topographically lower than the terrace and with no apparent signs of significant marine erosion. In fact, the Monte Gordo-Pedra Lume products are only covered by the $<25 \mathrm{~m}$ terraces. 


\subsection{Boa Vista}

Boa Vista is the Cape Verdean island with the highest felsic/mafic volumetric ratio (Serralheiro et al. 1974) and is one of the islands whose surface is more extensively covered with sedimentary rocks (mostly Holocene sands and Pleistocene terraces).

The island's volcanostratigraphy was defined by Serralheiro et al. (1974) and comprise, from the base to the top: Ancient Eruptive Complex; Monte Passarão Complex; Fundo de Figueiras Formation; Monte Caçador Formation; Pico Forcado Formation; Intercalated Sedimentary Deposits; Chão de Calheta Formation; Modern Pyroclastic Cones; Pleistocene Sediments; and Holocene Sediments (see Figure S2, and Table 2 in the main text).

\subsubsection{The Ancient Eruptive Complex}

The Ancient Eruptive Complex of Boa Vista occupies a large portion of the island's central surface. This unit is characterized by rocks of phonolitic nature, intensively intruded by dykes and large pockets of nepheline syenites with exotic minerals (Serralheiro et al. 1974). Sea-level constraints are unknown.

\subsubsection{The Monte Passarão Complex}

The following unit corresponds to the Monte Passarão Complex, a phonolitic series of subaerial flows, dykes, breccia and ignimbrites. This unit crops out around the margins of the Ancient Complex in the central area of the island, although the geometric relation with the latter unit is unclear (Serralheiro et al. 1974). Unit is possibly entirely subaerial and its products occur down to $\sim 50 \mathrm{~m}$ asl, so contemporaneous sea-level was below this elevation.

\subsubsection{The Fundo de Figueiras Formation}

The Fundo de Figueiras Formation comprises mostly effusive basaltic, submarine and subaerial products, and a dyke swarm (Serralheiro et al. 1974). The submarine flows crop out mostly 


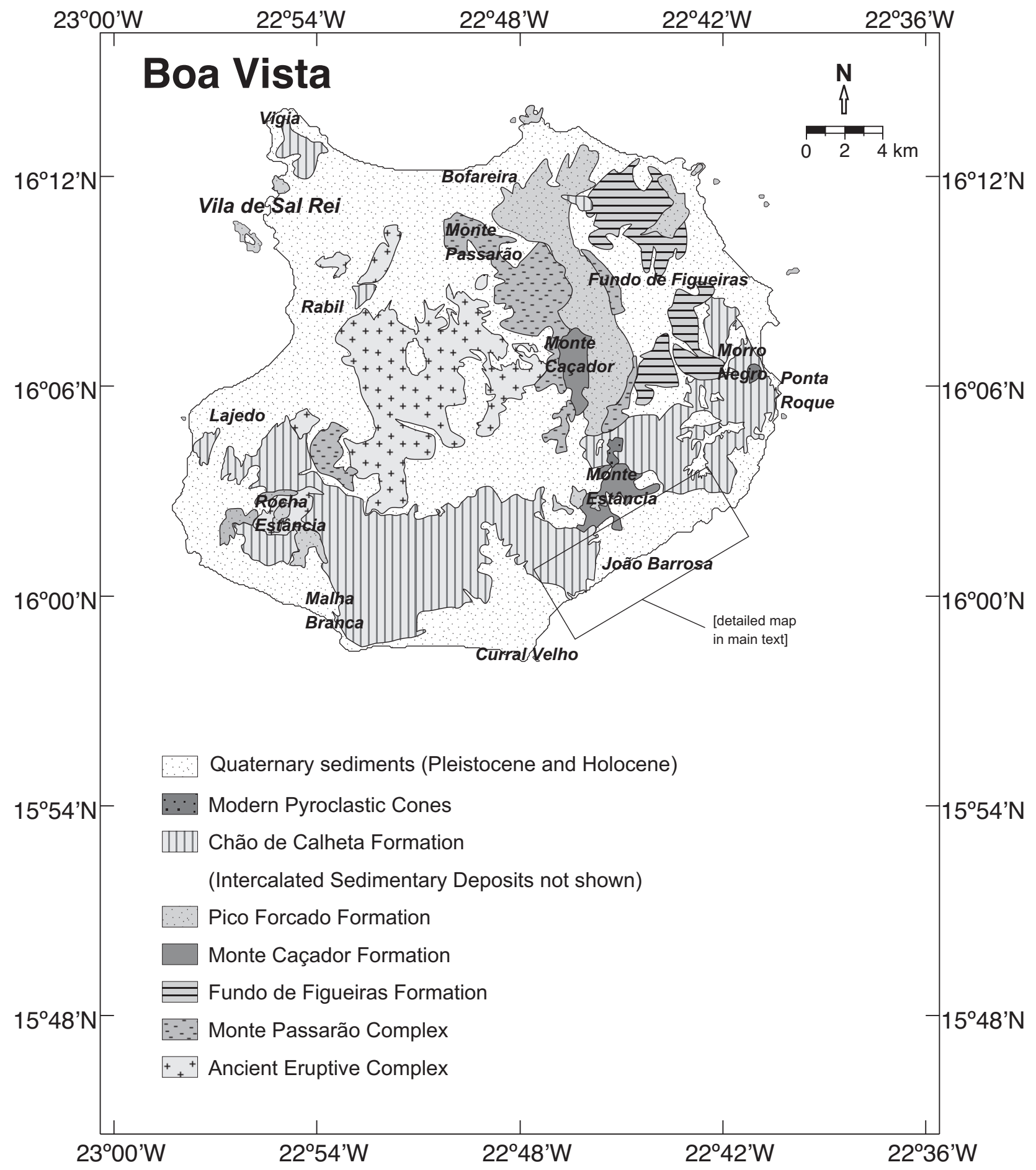

Figure S2: Geological map of Boa Vista, after Serralheiro et al. (1974). 
between Rocha Estância and Malha Branca, up to $\sim 35 \mathrm{~m}$ asl. They are rare in the rest of the island and their stratigraphic relation to the subaerial flows is not completely understood. Despite its small outcrop it is possible to infer that the relative sea-level height when these submarine flows were erupted was at minimum $35 \mathrm{~m}$ asl.

\subsubsection{The Monte Caçador Formation}

The Monte Caçador Formation, a generally effusive phonolitic series, is unconformably over the Monte Passarão phonolites and the Fundo de Figueira basalts Serralheiro et al. (1974). This unit seems to be entirely subaerial, exposed down to elevations close to the present sea-level.

\subsubsection{The Pico Forcado Formation}

The Pico Forcado Formation is yet another phonolitic unit, mostly subaerial flows and a few pyroclastic products (Serralheiro et al. 1974). The majority of the relief on the island, especially the eastern summits, are isolated structures and products belonging to this unit. It crops out in various positions, some close to the present sea-level.

\subsubsection{Intercalated Sediments}

A period of volcanic quiescence and erosion is suggested by the presence of terrestrial and marine sediments above the previous units and below the following ones. The marine deposits are found mostly on the coast, above the Pico Forcado and below the submarine lavas of the Chão de Calheta Formation, and can be followed further inland, through the more incised valleys (Serralheiro et al. 1974). They crop out close to the modern sea-level $(<10 \mathrm{~m}$ asl). These rocks are calcarenites and compact limestones, fossiliferous, sometimes reach $10 \mathrm{~m}$ of thickness, and correspond to shallow water deposits (Serralheiro et al. 1974). 


\subsubsection{The Chão de Calheta Formation}

According to Serralheiro et al. (1974) the next unit - the Chão de Calheta Formation - is the the most important basaltic unit found on the island. This effusive series, subaerial and submarine, is only found on the periphery of the island where it covers large areas. The submarine flows are mostly found on the coast (particularly in the east), frequently underlain by the marine sediments, and reach considerable individual thicknesses (Serralheiro et al. 1974). They crop out up to 30 to $40 \mathrm{~m}$ asl, and the passage zone to the overlying subaerial flows is frequently observable.

\subsubsection{Recent post-erosional volcanic activity}

A few rare modern pyroclastic cones of basaltic nature can be found in the island (e.g. Morro Negro), with small associated flows (Serralheiro et al. 1974). These cones are only found inland above 40 to $50 \mathrm{~m}$ asl and submarine products belonging to this stage seem to be absent.

\subsubsection{The Pleistocene sediments and wave-cut surfaces}

Above the previous units, and covering extremely large areas, Pleistocene marine terraces, and associated wave-cut surfaces, can be found at the following elevations: :2-3 m, 4-8 m, 10-15 $\mathrm{m}, 18-28 \mathrm{~m}, 30-45 \mathrm{~m}, 50-60 \mathrm{~m}, 65-70 \mathrm{~m}, 70-80 \mathrm{~m}$, and 90-105 m asl (and eventually $130 \mathrm{~m}$ asl). The great majority of the Pliocene terraces are composed of well-cemented bioclastic grainstones, wackestones, boundstones, and mudstones, frequently recrystallized and variably affected by processes of calcrete formation (typical of this type of arid environment). Internal sedimentary structures are sometimes observable, normally dominated by plane-bedding and lamination and less frequently by cross-bedding and cross-lamination. The construction of one deposit at the expense of previous (normally higher) deposits, by erosion and redeposition, probably occurred in places. The evidence is the presence of a conglomeratic facies rich in lithoclasts/intraclasts at the base of the foreshore face built in the older deposits. Conglom- 
eratic and micro-conglomeratic facies comprising well rounded volcanic clasts and occasional lithoclasts/intraclasts supported by a calcarenitic matrix can also be found generally at the base of some terraces or at the base of steep foreshores built in the igneous bedrock, indicating higher energy environments. Fossil associations include solitary corals (in the high energy facies), rhodoliths, bivalves, gastropods, and occasional echinoderms. Trace-fossils (burrows identified as belonging to the ichnogenus Palaeophycus) are also very common, especially in the wackstone/mudstones facies, normally occurring atop the more extensive deposits (e.g 10$15 \mathrm{~m}$ level). Good areas to observe the terraces include: all the south coast, the Rabil-Lajedos, Bofareira and Vigia. The Rabil-Lajedos ridge (40-100 m asl) is notable for the extent and thickness of the carbonate sediments that constitute its crest, due to stacking of several generations of terraces and dunes.

In contrast with this usual morphology, in some places it is possible to find steeply dipping deposits, normally of smaller extent and thickness. These are composed of grainstones exhibiting plane-bedding and a top surface dipping $20^{\circ}$ to $25^{\circ}$ seaward (e.g. near Ponta do Medronho, at 25-45 m asl). Their occurrence along constant elevations and the presence of trace-fossils (vertical burrows of the ichnogenus Ophiomorpha or Thalassinoides) suggest these sediments to be marine rather than aeolian in origin. We interpret these as steep foreshore beach deposits.

\subsection{Maio}

The first full stratigraphic description of the island was produced by Serralheiro (1970) and was later revised and redefined by Stillman et al. (1982). According to Stillman et al. (1982), it includes: Mesozoic Basement Complex; Central Igneous Complex; Casas Velhas Formation; Pedro Vaz Formation; Malhada Pedra Formation; Monte Penoso Formation; Quaternary Sediments (see Figure S3, and Table 3 in the main text). 


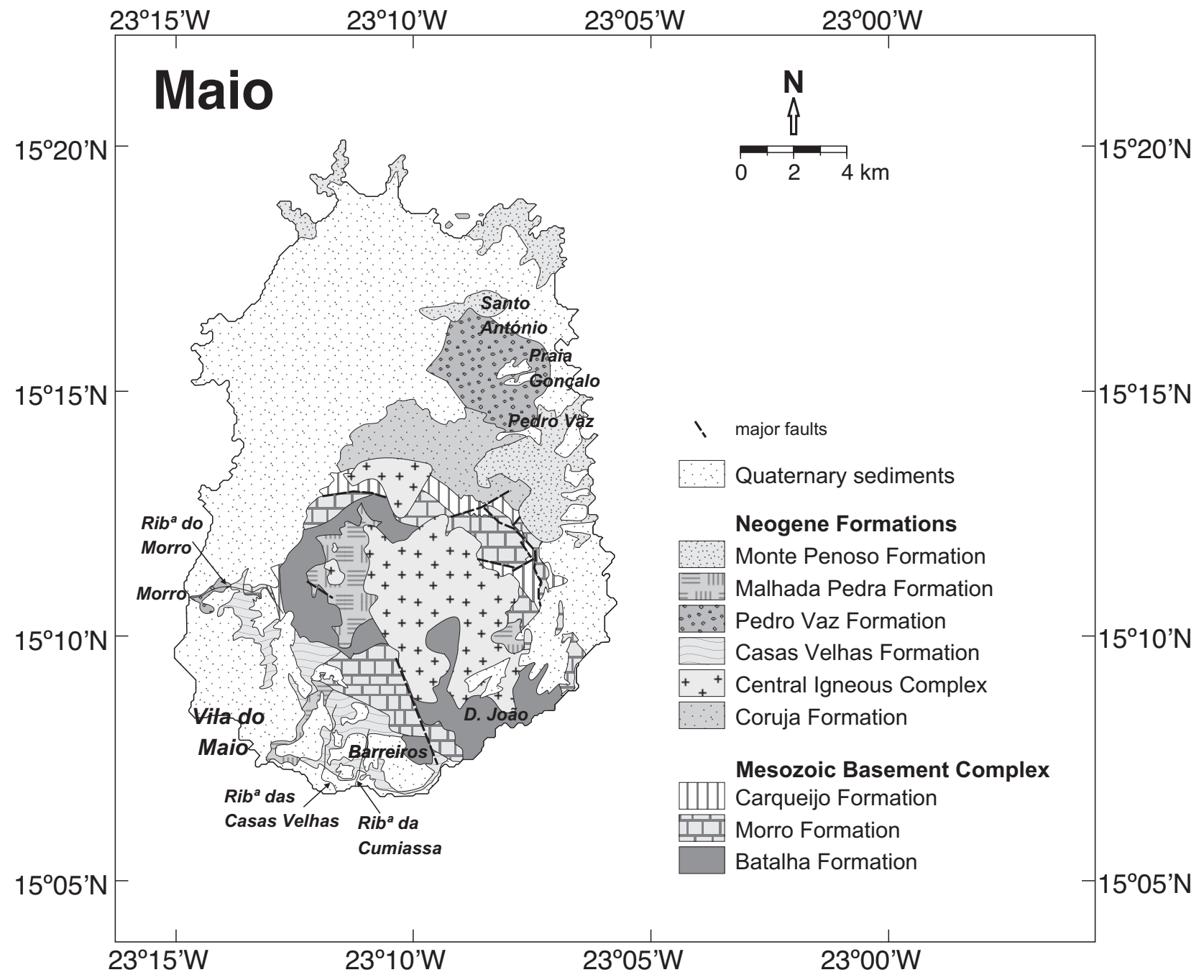

Figure S3: Geological map of Maio, after Serralheiro (1970), Stillman et al. (1982) and Holm et al. (2008). 


\subsubsection{The Mesozoic Basement Complex}

The Mesozoic Basement Complex occupies up to $20 \%$ of the island's area and includes: the MORB type volcanic rocks of the Batalha Formation, the limestones of the Morro Formation, the shales and thin-bedded limestones of the Carqueijo Formation, and the tuffs and conglomerates of the Coruja Formation. The Coruja Formation was later attributed to the Early Miocene by Holm et al. (2008). The problematic aspect of these shallow marine conglomerates and tuffs is the fact that they include clasts of alkaline rocks, leading to previous interpretations for an earlier start of island volcanism (Late Cretaceous). A constraint on the correct age of this unit is crucial to dating the emergence of the island and to dating the contemporaneous relative sea-level height.

The Mesozoic Basement Complex is folded and faulted, flanking the Central Igneous Complex. The mechanism responsible for its upheaval is not yet completely understood, but is thought to be related to updoming associated with plutonic activity and island volcanism (Serralheiro 1970; Stillman et al. 1982).

\subsubsection{The Central Igneous Complex}

The Central Igneous Complex corresponds to a series of intrusive bodies composed of pyroxenites, essexites and syenites, densely cut by a swarm of sills and dykes of varied composition (Serralheiro 1970; Stillman et al. 1982). The age of these intrusions is still debatable but the 18-21 Ma interval seems to best represent it (Holm et al. 2008).

\subsubsection{The Casas Velhas Formation}

The Casas Velhas Formation seems to correspond to the first extrusive stage of Neogene volcanism (Stillman et al. 1982). This unit mostly crops out in the valleys of the SW of the island, and comprises submarine and subaerial lavas, according to Stillman et al. (1982). These authors state that the proximity of a Neogene coastline is suggested by the presence of lava delta 
deposits with hyaloclastites and isolated pillows, with rare subaerial flows atop. Since these submarine flows crop out at elevations up to 35-40 $\mathrm{m}$ asl we infer an elevation of $\sim 40 \mathrm{~m}$ for the sea-level position. This unit was apparently emplaced sometime around 10 Ma (Mitchell et al. 1983).

\subsubsection{The Pedro Vaz Formation}

The Pedro Vaz Formation comprise conglomerates and tuffs synchronous of the Casas Velhas Formation, representing a series of immature fluvial fanglomerates with possible marine sediments (Stillman et al. 1982). The coexistence of subaerial and submarine facies can be explained by rapid vertical movements (Stillman et al. 1982), or more simply by the high-frequency variations that characterize the eustatic curve.

\subsubsection{The Malhada Pedra Formation}

The Malhada Pedra Formation is the result of extensive subaerial volcanism, creating large quantities of plateau lavas around 9-7 Ma, unconformably overlying the previous units (Stillman et al. 1982; Mitchell et al. 1983). The products of this volcanic stage can presently be found down to lower elevations, close to the present sea-level.

\subsubsection{The Monte Penoso Formation}

Following the effusive volcanism of Malhada Pedra, the Monte Penoso Formation corresponds to the remains of a prominent strato-volcano, now eroded (Stillman et al. 1982). This seems to have erupted around $7 \mathrm{Ma}$, the last reported age for volcanic activity in Maio (Mitchell et al. 1983). These products can presently be found down to present sea-level.

\subsubsection{Mio-Pliocene sediments}

Mio-Pliocene calcarenites were described by (Serralheiro 1970) on the coast to the south of Vila do Maio village. They are presently at sea-level and are unconformably covered by a 
Quaternary terrace. Bivalves and gastropods fossils are present in these sediments. Their age was determined by the presence of Procarcharodon megalodon teeth (Serralheiro 1970). The relationship between these sediments and the volcanic units is still unclear but they seem to overly the Malhada Pedra lavas.

\subsubsection{Quaternary sediments and wave-cut surfaces}

On top of the previous lithologies, extensive Pleistocene and Holocene deposits can be found. The Pleistocene deposits are associated with contemporaneous wave-cut surfaces, constituting a good record of relative sea-level heights (these are described in the main text)

\subsection{Santiago}

The volcanostratigraphy of the island comprises the following main units, from the oldest to the youngest (Serralheiro 1976): Ancient Eruptive Complex; Flamengos Formation; Orgãos Formation; Pico da Antónia Eruptive Complex; Assomada Formation; Monte das Vacas Formation; and Quaternary sediments (see Figures S4 and S5, and Table 1 in main text). Recent radiometric studies suggest, however, that Assomada and Monte das Vacas formations are likely to be different facies of the same volcanic episode (Holm et al. 2008).

Due to the variety and complexity of Santiago's volcanostratigraphy, we shall only describe key cross-sections that best evidence the sea-level height(s) mentioned in the main text.

\subsubsection{The Ancient Eruptive Complex}

The Ancient Eruprive Complex of Santiago constitutes the basement unit of the island, and comprise several distinct products of basaltic, phonolitic and carbonatitic nature. The whole unit is deeply eroded, weathered, and intensely intruded by a dyke swarm and pockets of plutonic rocks (Serralheiro 1976). The Ancient Eruptive Complex country rock is rarely observed but seems to be mostly constituted by submarine volcanic products. Fragments of sea-floor (MORB-type basalts) seem to be present within the sequence of the Ancient Eruptive Complex, 


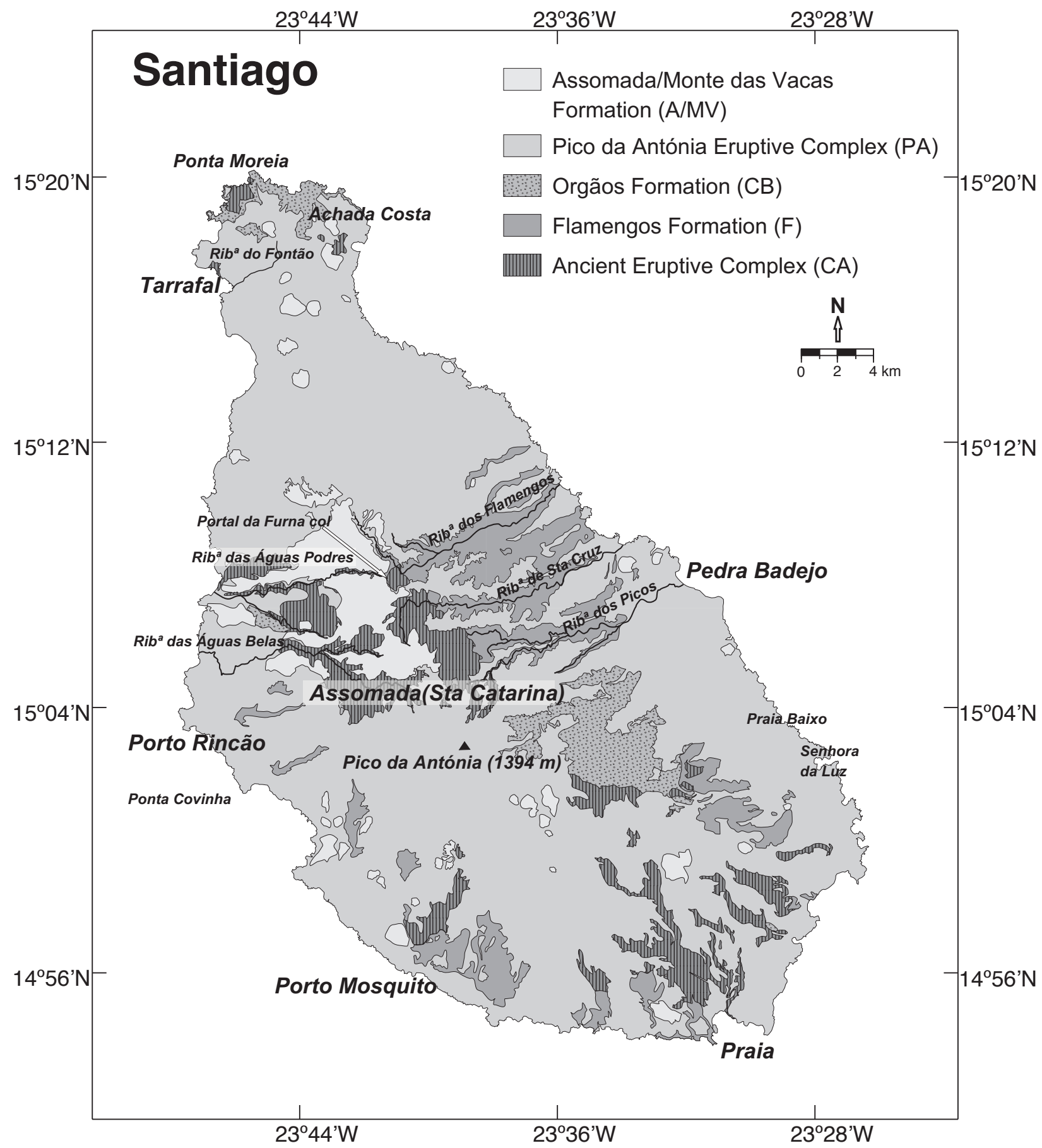

Figure S4: Geological map of Santiago, after Serralheiro (1976). 
as suggested by Gerlach et al. (1988) and Davies et al. (1989), dragged by a process that is still poorly understood.

The existence of sea-floor fragments and the possible existence of submarine products within the sequence of the Ancient Eruptive Complex imply significant uplift. However, it is out of the scope of this work to reconstruct all the events that took place to form this unit, and to unfold its complexity. Thus, we do not take into account inferences of sea-level based in the Ancient Eruptive Complex of Santiago.

\subsubsection{The Flamengos Formation}

The Flamengos Formation is entirely submarine. The highest point where the Flamengos Formation crops out is in the Portal da Furna col (Assomada). Here, the headward erosion of the Ribeira das Águas Podres and Flamengos valleys exposes the submarine sequence up to $450 \mathrm{~m}$ asl. The present sequence exhibits clusters of individual pillows floating in a weathered hyaloclastitic breccia, unconformably covered by subaerial lavas corresponding to the Pico da Antónia Volcanic Complex and Assomada/Monte das Vacas Formations. Since the younger subaerial flows are filling a palaeo-topography superimposed on the Flamengos Formation sequence, it is not possible to quantify how much of this unit was eroded, thus making it impossible to estimate the palaeo-depth of emplacement for the submarine volcanism. Nevertheless an elevation of $\sim 450 \mathrm{~m}$ asl should be considered as the minimum height for the palaeo sea-level.

\subsubsection{The Pico da Antónia Volcanic Complex}

The submarine products of Pico da Antónia Volcanic Complex are ubiquitous along the coast. However, the lower course of some of the central valleys present the best natural cross sections for sea-level height studies. From these we highlight the Flamengos, the Ribeira de Santa Cruz,

and the Ribeira dos Picos valleys in the eastern part of the island, and the Ribeira das Águas Belas in the western part of the island. The stretches of coast south of Porto Rincão and north 
of Porto Mosquito in the western part of the island, are also good examples. The northern tip of the island is also an excellent region for sea-level palaeo-marker studies. These localities are described below.

In the mouth of the Flamengos valley, the exposed sequence reveals a palaeo-topography carved in Flamengos Formation submarine lavas and covered by Pico da Antónia Volcanic Complex submarine and subaerial lavas. The Flamengos Formation locally exhibit seawardly dipping pillow-lavas, cropping out at elevations up to $100 \mathrm{~m}$ asl near the river mouth, and at increasing elevations upstream (until $450 \mathrm{~m}$ at the head of the valley). The Pico da Antónia lower member submarine lavas are found only at the very end of the valley, "fossilizing" the palaeo-topography imposed on the Flamengos lavas by a very steep contact suggesting a former coastline. In this locality the Pico da Antónia submarine flows are characterized by very steep dipping pillows (to seaward) and can be found up to elevations of $140 \mathrm{~m}$. The later subaerial flows of Pico da Antónia (upper member) cover the sequence, unconformably. Thus, the maximum height locally found for the Pico da Antónia submarine flows, at $140 \mathrm{~m}$ asl, mark a minimum relative sea-level height, contemporaneous with the submarine flows. Since in the vicinity it is possible to find the younger subaerial flows at lower elevations, one may infer that sea-level was lower during the emplacement of these flows.

The west bank of Ribeira de Santa Cruz (also called Ribeira da Boaventura) is another key cross section for freeboard studies. The bottom of the valley is carved in Flamengos Formation pillow-lavas and submarine pyroclasts. The top of this unit rises steeply further upstream, in the Ribeirão Boi area, and is covered by a thick sequence of Pico da Antónia lower member submarine flows, again filling the palaeo-topography. Thin marine conglomerates and calcarenites are reported between the two submarine units (Serralheiro 1976). The highest outcrops of Pico da Antónia lower member submarine flows can be found near Ribeirão Fundo, at $\sim 235 \mathrm{~m}$ asl, or at $\sim 245 \mathrm{~m}$ asl in the adjacent valleys of Ribeirão Seco and Carriçal. There, they are steeply against the older submarine flows and are unconformably covered by the later 
Pico da Antónia subaerial flows (upper member). We thus infer a minimum palaeo-position for contemporaneous sea-level at $\sim 250 \mathrm{~m}$ asl.

A similar situation can be found in the Ribeira dos Picos valley, where the Pico da Antónia lower member submarine flows yet again cover a steep palaeo-topography imposed on the Flamengos Formation, and whose top can be found in both banks at $\sim 225 \mathrm{~m}$ (Achada Vianga) and $\sim 200 \mathrm{~m}$ (João Toro), covered by the later subaerial flows (see fig. 3a in the main text). This geometry suggests a similar contemporaneous sea-level height above $230 \mathrm{~m}$ asl.

The western flank of Santiago island is also fertile ground for freeboard studies. The lower course of the Ribeira das Águas Belas (see fig. 3b) is entirely carved in a sequence comprising Pico da Antónia lower member submarine flows unconformably covered by subaerial lavas belonging both to Pico da Antónia Volcanic Complex (upper member) and Assomada/Monte das Vacas Formations. The submarine sequence extends close to $5 \mathrm{~km}$ inland from the river mouth, and is constituted of steeply inclined pillow-lavas, pillow breccias, and hyaloclastites, dipping $25^{\circ}-35^{\circ}$ seaward. Its top is eroded but its highest point can be found in Chão do Penedo area, convincingly up to $\sim 270 \mathrm{~m}$, and possibly up to $290 \mathrm{~m}$ or even $320 \mathrm{~m}$ asl (a slope deposit covers the boundary). We therefore infer a minimum palaeo-position of sea-level at $\sim 270 \mathrm{~m}$ asl, contemporaneous with these submarine flows.

The coast between Porto Rincão and Ponta da Covinha exhibits a sequence composed of Pico da Antónia lower member submarine flows unconformably covered by two sequences of subaerial flows (both interpreted to belong to the Pico da Antónia Volcanic Complex upper member). The later subaerial sequence spilled to lower levels, partially covering the boundary between the submarine and first subaerial series. This boundary is irregular but clearly visible in places, indicating erosion prior to the extrusion of the succeeding subaerial flows, marked by the occasional presence of a thin conglomerate bed $(<2 \mathrm{~m})$ with large rounded boulders. The top of the submarine flows reaches up to $80-90 \mathrm{~m}$ asl, and up to higher elevations further inland along the valleys. 
The Porto Mosquito area presents a similar sequence. The exposed sequence comprises a lower package composed of pillow-lavas and thin hyaloclastite beds, dipping seaward and reaching an elevation of $\sim 80 \mathrm{~m}$, and an upper package of subaerial flows (both attributed to the upper member of Pico da Antónia Volcanic Complex). This elevation is interpreted as a minimum height for the contemporaneous relative sea-level.

The northern peninsula of Santiago is a plateau whose sequence comprises, from the base to the top (Silva et al. 1981): a carbonatitic/nephelinitic extrusive complex (Ancient Complex); shallow marine epiclastic carbonatitic sediments; bioclastic calcarenites; and Pico da Antónia plateau basalts (see fig. 3c). The epiclastic sediments and the bioclastic calcarenites are best observed on the coast between Achada Costa and Ponta Moreia, and in the Ribeira do Fontão valley. The thickness of the sedimentary package is variable but can locally reach $>100$ m. The bioclastic calcarenites are particularly abundant in Ribeira do Fontão valley, where they crop out intercalated with pillow-lavas. These sediments are frequently conglomeratic at the base, with large volcanic boulders and become more calcarenitic toward the top. Fine grained facies are sometimes bioturbated (box-work burrows of the ichnogenus Ophiomorpha or possibly Thalassinoides) and exhibit a macro-fossil association comprising large bivalves, gastropods, rhodoliths, bryozoa, echinoids and rare corals, suggesting a shallow marine to beach environment. The basaltic plateau is composed of thick submarine sheet flows and pillow-lavas (attributed to the lower member of Pico da Antónia Volcanic Complex), whose top forms a regular surface at 175-190 m asl and is covered by later subaerial flows (attributed to the upper member of Pico da Antónia Volcanic Complex). These later flows preserved the flat morphology on the top of the plateau but spilled to lower levels (filling an incipient palaeo-topography imposed on the previous sequence) without reaching the sea (indicating that the relative sea-level was already significantly lower). Above these units it is possible to find phonolitic domes and lavas (still included in the Pico da Antónia volcanic sequence) and younger strombolian cones (attributed to the Assomada/Monte das Vacas Formation) but none 
$\therefore ._{2}$ Assomada/Monte das Vacas Formation (A/MV) (1 - flows; 2 - cones) [1.1 - $\left.0.7 \mathrm{Ma}\right]$

${ }^{1}$ Pico da Antónia Eruptive Complex (1- upper subaerial member, PA; 2 - lower submarine member, PA $\mathrm{sub}_{\text {sub }}$ [3.3 - $2.2 \mathrm{Ma}$ ]

Orgãos Formation (CB)

$\square$ Flamengos Formation (F) [4.6 Ma]

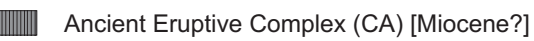

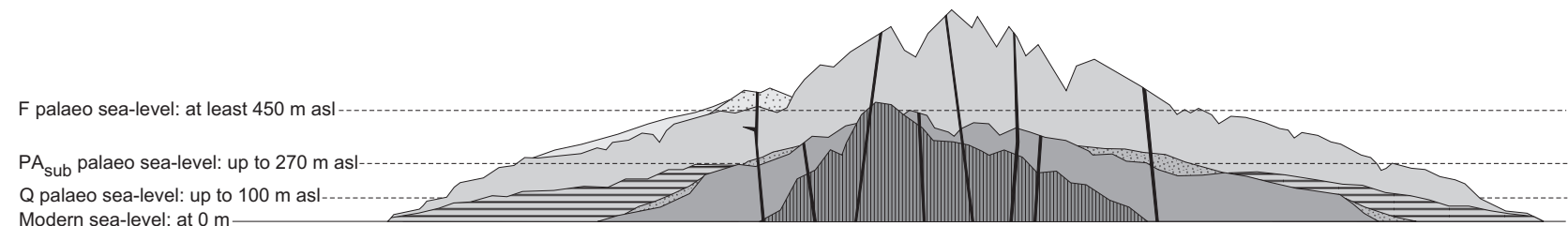

Figure S5: Idealized cross section of Santiago showing the geometric relations between the units, and the information of relative past sea-levels inferred from the volcanostratigraphy. Note the increase in elevation with increasing age. Stratigraphic units after Serralheiro (1976), and the geochronology after Holm et al. (2008).

show clear submarine morphology. The top of the submarine sheet flows, a very regular feature, can be used as a marker for the relative sea-level at the time of their extrusion.

\subsubsection{The Assomada/Monte das Vacas Formation(s)}

The Assomada/Monte das Vacas Formation seems to have produced exclusively subaerial products, however this unit is only mapped above $100 \mathrm{~m}$ asl, with the exception of only two cones whose base is at 40-50 $\mathrm{m}$ asl. Thus we infer that the contemporaneous sea-level was generally below $40 \mathrm{~m}$. The age relationship between this unit and the Quaternary sediments is not clear, but both units are probably partially synchronous.

\subsubsection{Quaternary sediments and wave-cut surfaces}

Santiago exhibits narrow and poorly developed Quaternary wave-cut surfaces and rare contemporaneous sediments. However several levels can be distinguished at 2-4 m, 5-10 m, 15-25 m, 30-40 m, 50-60 m, 60-80 m, and 80-100 m asl (Serralheiro 1976). For a detailed description of these features we suggest the reading of Serralheiro (1976). We shall mention some of the best places to observe these features. 
In the western coast, between Porto Rincão and Ponta da Covinha, the whole sequence was carved during Quaternary times by marine erosion forming a complex geomorphology with evidence for marine abrasion surfaces at 15-25 m, 30-40 m, 60-80 m, and 85-100 m asl (Serralheiro 1976). As noted by Serralheiro (1976), significant boulder accumulations can be found covering the abrasion surface between 80 and $100 \mathrm{~m}$, and scarce conglomeratic outcrops exist in Porto Rincão between 15 and 25 m.

In the region of Porto Mosquito, a composite marine abrasion surface was cut during different periods of the Quaternary, creating a prominent sea cliff. This surface is presently at 20-40 $m$ asl and probably corresponds to two or three different high stands (it is possible to distinguish two or three different levels in this surface, sometimes marked by boulder accumulations). The backbeach cliff is presently a few hundred meters distant from the sea.

In the eastern coast, sediments can be found at Praia Baixo and Senhora da Luz, or even further south. In Praia Baixo the sediments comprise conglomerates and calcarenites rich in bivalves, gastropods, echinoids and barnicles. They probably correspond to the 15-25 m deposit, however, its base can be found at lower elevations since the deposit can be up to $20 \mathrm{~m}$ thick (Serralheiro 1976). In Senhora da Luz, several fossiliferous deposits can be found at 15-25 m, 5-10 and at 2-4 m (Serralheiro 1976).

\section{São Nicolau}

The volcanostratigraphy of the island comprises (Macedo et al. 1988) from oldest to youngest: Ancient Eruptive Complex; Late Miocene Marine Sediments; Figueira de Coxe Formation; Conglomerate-Breccia Deposit; Main Eruptive Complex; Preguiça Formation; Monte Gordo Formation; and Quaternary sediments (see Figure S6, and Table 5 in the main text). 


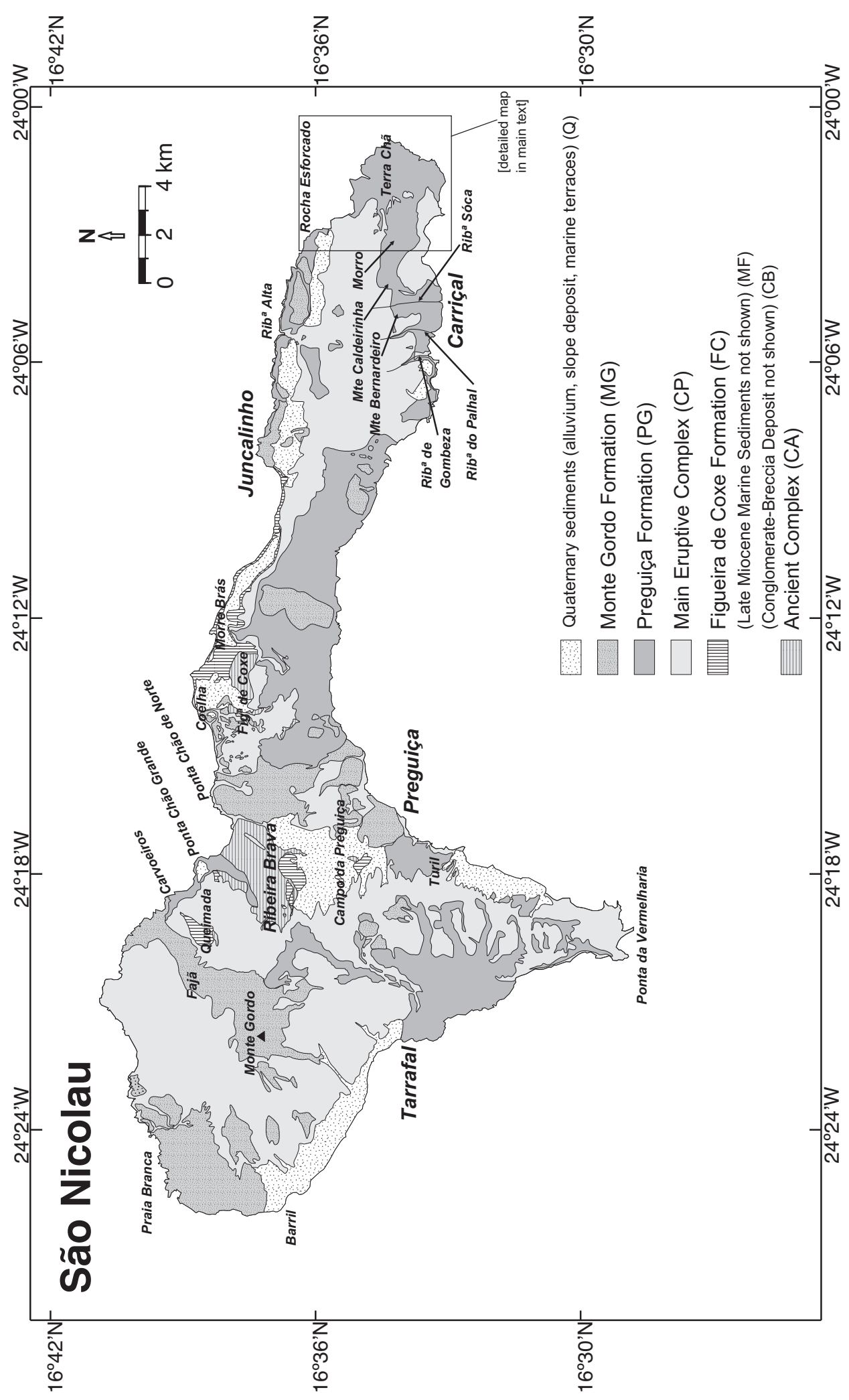

Figure S6: Geological map of Sã Nicolau, modified from Macedo et al. (1988). 


\subsubsection{The Ancient Eruptive Complex}

The Ancient Eruptive Complex of São Nicolau is especially well exposed in the Ribeira Brava valley. This unit is intensely weathered and intruded by an important dyke swarm (up to $90 \%$ of the exposed sequence), making it very difficult to observe what was the country rock before the intrusion of the dykes. However, the observable material is intensely altered to a yellow clay of probable palagonitic nature, suggesting it to be of hyaloclastitic nature. The whole unit, including the large majority of the dykes that cut through its sequence, is clearly truncated atop by an important erosive surface preserved by the overlying units. This unconformity is well exposed in the right bank of Ribeira Brava, below the Figueira de Coxe pyroclasts. Thus, the lithologies that compose the Ancient Eruptive Complex are older than any of the dated units by Duprat et al. (2007) and remain undated.

A series of eroded phonolitic vents and associated products were also included in the Ancient Eruptive Complex by Macedo et al. (1988) and described as subaerial in nature. The presence of possible subaerial products in the sequence of the Ancient Eruptive Complex needs further investigation because of its significance regarding uplift reconstructions.

\subsubsection{The Late Miocene Marine Sediments}

The Late Miocene Marine Sediments were well described by Serralheiro \& Ubaldo (1979) and later by Bernoulli et al. (2007). They comprise calcarenites rich in fossils, with an age comprehended between 11.8 and 5.8 Ma or even between 6.2 and 5.8 (Bernoulli et al. 2007). The sediments occur in discontinuous outcrops ranging from 170 to $227 \mathrm{~m}$ asl, and overly products of the Ancient Eruptive Complex including a dismantled phonolitic intrusion. Torres \& Soares (1946), and later Bernoulli et al. (2007), proposed that this intrusion corresponds to a cryptodome who warped the sediment beds when it was emplaced, tilting them to the $\mathrm{W}$. However, we disagree with this view and we agree with the interpretations by Serralheiro \& Ubaldo (1979) and Macedo et al. (1988) that consider this intrusion to be older than the sediments and part 
of the bedrock where the later were deposited. Our opinion is based in the fact that no baking or peperitic structures can be seen in the sediments near the contact, as one would expect if the contact was intrusive in nature.

\subsubsection{The Figueira de Coxe Formation}

The Figueira de Coxe Formation is exclusively composed of submarine lavas, cropping out from the present sea-level up to elevations close to $260 \mathrm{~m}$ asl. This unit was originally described in the Figueira de Coxe region (from where the formation takes its name) where they are best preserved and reach higher elevations. The unit is eroded and loses elevation towards Juncalinho in the east, being covered by the Main Eruptive Complex subaerial lavas. However, this formation also occurs in Campo de Preguiça, Ribeira Brava and Queimada regions where they reach similar elevations (above 200 masl). Thus we do not see evidences for the existence of a N-S fault to the west of Figueira de Coxe, and the possible tilting towards the east, proposed by Duprat et al. (2007). In our view, the irregularities observed atop the Figueira de Coxe Formation are due to an important period of erosion correlated to the Conglomerate-Breccia Deposit of Macedo

et al. (1988) and the marine sediments found at the base of the Main Eruptive Complex (well exposed in the eastern part of the island).

The products of this unit mostly comprise pillow-lavas and pillow and hyaloclastite breccias. However, in Ribeira Brava is composed of submarine pyroclasts (Macedo et al. 1988) suggesting the presence of an important eruptive center in this place.

The Figueira de Coxe Formation corresponds to Stage 1 defined by Duprat et al. (2007), attending to the locations and stratigraphical position of the samples collected by these authors, as described in their paper. 


\subsubsection{The Main Eruptive Complex and the Preguiça Formation}

The Main Eruptive Complex corresponds to the main shield building stage of São Nicolau, and constitutes the bulk of the exposed edifice. This unit seems to correspond to Stage 2 defined by Duprat et al. (2007), attending to the locations and stratigraphical position of the samples collected by these authors, as described in their paper. Likewise, the Preguiça and Monte Gordo Formations also seem to correspond respectively to Stage 3 and 4 of Duprat et al. (2007).

The easternmost part of the island constitutes an important case-study of relative sea-level change (see figures 4 and 5 in the main text). Here a headland of the Main Complex was "fossilized" by the later flows that formed the extensive lava delta of Terra Chã. The shape of this palaeo-headland can be deduced by the $\sim 60 \mathrm{~m}$ geomorphological step that runs from Talhada to Ribeira de Castilhiano, separating the gently dipping higher elevations west of this line from the flat surface of the Terra Chã plateau to the east. The young lava flows covered the Main Complex sequence, in-filled the existing east-draining valleys, and spilled out to form the Terra Chã volcanic delta, extending the island to the east. The unconformity thus created, and the sequence of both the underlying and overlying units, can be best observed in the valleys of Ribeira de Castilhiano, Ribeira de António Barbacante, Covoada de Bodela, Ribeira de Falcão (an extension of the previous two confluent valleys), and in the southeast coast between Ponta Barroso and Ponta Talhada. These flows probably originated in a WNW-ESE lineament of vents that include Monte Caldeirinha and Morro cones.

The headland sequence comprises, from the base to the top: Ancient Complex (?); Marine carbonates; Main Complex submarine lower member; and Main Complex subaerial upper member. In this area the passage zone between the submarine and subaerial members of the Main Complex can be found regularly at $\sim 100 \mathrm{~m}$ asl (in Ribeira de Castilhiano, Ribeira de António Barbacante, Ribeira de Covoada de Bodela and Talhada).

The Castilhiano valley provides a good cross-section of the headland sequence, despite its 
lower slopes being covered by scree. The bottom of the valley is carved in the Ancient Complex (?) and comprises intensively weathered tuffs (submarine?) intruded by steep dipping dykes. It crops out up to $\sim 80 \mathrm{~m}$ asl. The marine carbonates reach a thickness up to $6 \mathrm{~m}$ and lie unconformably over the previous unit. The carbonates are characterized by a framework of rhodoliths, enveloped in a fine bioclastic grainstone matrix. Fossils of echinoids and bivalves are also present. By comparison with other present and past environments (Bosence 1983; Webster et al. 2006), we suggest these sediments correspond to a medium energy shelf environment. The assemblage of echinoid/rhodoliths, together with the indications of a medium energy environment, suggests a palaeo-depth ranging 10 to $50 \mathrm{~m}$. Above the sediments, up to $102 \mathrm{~m}$ asl, the Main Complex submarine sequence are composed of a $3 \mathrm{~m}$ thick submarine sheet flow immediately overlying the carbonates, and hyaloclastite and pillow breccia above it. Finally, atop the pile, the subhorizontal Main Complex subaerial flows crop out. The whole sequence is also superbly exposed on the coast running from Boca da Ribeira to Ponta de Tope de Capa. Very similar lateral equivalents of the previously described carbonates can also be found in the adjacent valley of Covoada de Bodela and on the coast in Talhada-Ponta Barroso.

In the Talhada region the observable sequence comprises: basal outcrops of Ancient Complex (?) tuffs and lavas (up to $20 \mathrm{~m}$ asl); compact marine carbonates lying unconformably over the previous unit and up to $5 \mathrm{~m}$ thick, with occasional individual pillows included in the sediments as clasts; Main Complex submarine flows from 5-20 m asl up to $\sim 100 \mathrm{~m}$ asl; and Main Complex subaerial flows. Close to the top of the submarine sequence, a $1 \mathrm{~m}$ thick wellcemented calcarenite bed, rich in bivalves, corals, rhodoliths and echinoids, can be found within the pillow-lavas.

The younger lavas that constitute the Terra Chã delta comprise a lower submarine member mainly composed of steeply eastward-dipping breccia and pillow foresets covered by flat lying subaerial flows. A discontinuous calcarenite bed of a few meters thick is occasionally present underneath the sequence, lying unconformably over the older formations. The passage zone in 
the delta sequence is found very regularly at $\sim 40 \mathrm{~m}$ asl. In Boca da Ribeira (Castilhiano), the submarine flows overlie a 1 to $3 \mathrm{~m}$ thick conglomerate (with calcarenitic matrix), very rich in large oysters. Boulders of pillow-lavas are present in the deposit. This deposit, in turn, unconformably overlies intensively weathered tuffs possibly belonging to the Ancient Complex (?). The young lavas were considered to be part of the Main Complex by Macedo et al. (1988), but they must be considered as part of the younger post-erosional Preguiça Formation, due to their field relations and geochronological data. Radiometric ages determined by Duprat et al. (2007) in the young flows at Ribeira Falcão yielded ages between 1.7 and 1.15 Ma.

These two very regular passage zones, in the Main Eruptive Complex and in the younger lava delta, respectively indicate two different relative sea-level heights at $\sim 100 \mathrm{~m}$ and $\sim 40 \mathrm{~m}$ above the present sea-level.

Further west in Carriçal area it is possible to observe a marine abrasion surface carved in the Main Complex, covered by young subaerial lava flows that we group with the Preguiça Formation. The Main Complex sequence is composed of a submarine lower member of seaward dipping foresets of hyaloclastite breccia and pillows and an upper member of subaerial subhorizontal lavas. The passage zone is best observed in the Ribeira do Palhal valley, $800 \mathrm{~m}$ upstream from the village of Carriçal. In this location it is found at an elevation of $\sim 70 \mathrm{~m}$ asl, suggesting a variation in sea-level height during the formation of the Main Complex.

The abrasion surface, extending $600 \mathrm{~m}$ inland, was cut in the submarine lavas and it is currently at 15 to $35 \mathrm{~m}$ asl. It is covered by a thin sequence of subaerial lava flows that spilled from the proto-valleys of Ribeira do Palhal and Ribeira de Gombeza. The vents that originated these flows were not identified. In places it is possible to find a thin conglomeratic deposit between the two sequences. Lava flows from the Monte Bernardeiro and Monte Caldeirinha cones were also erupted around the same time, creating the recognizable morphology of Carriçal effusive fan (probably around $1 \mathrm{Ma}$, the age determined by Duprat et al. (2007) in Ribeira de Sóca). The flows from Ribeira do Palhal reached the contemporaneous shore and covered the fossiliferous 
estuarine deposits of the same creek. This suggests that the coastline, and that the sea-level height were similar to the present day's. The sequence, including the estuarine sediments, can be observed in Ribeira do Palhal river mouth, near Carriçal. These sediments comprise an $8 \mathrm{~m}$ thick series of imbricated conglomerates, intercalated with calcarenites/sandstones with cross-lamination, rich in bivalves and gastropods.

The young subaerial lavas were in turn submerged and partially eroded to create another marine abrasion surface, presently at 20 to $30 \mathrm{~m}$ asl and marked by the presence of scattered outcrops of shallow marine carbonates. These are conglomeratic and rich in fossils of corals, bivalves, gastropods and echinoids, an association typical of a high energy environment. A small cliff, etched in the young flows during this period, can be seen 300 meters to the east of Carriçal village.

In the central and western part of the island the Main Complex submarine lower member is usually covered by young flows and the passage zone is difficult to observe. We studied the sequence in Traje Ribeirão de Cruz and Turil area (Preguiça) where the top of the submarine flows reaches $\sim 90 \mathrm{~m}$ asl. These outcrops reveal a sequence composed of submarine lavas (pillows and sheet flows) with occasional lenses of marine carbonate beds. The carbonates are mostly calcarenites, conglomeratic at the base, and rich in bivalves, gastropods, bryozoa, and sporadic corals. The maximum thickness of these lenses is between 12 and $15 \mathrm{~m}$ (Macedo et al. 1988). This constitutes further evidence for a relative sea-level height close to $100 \mathrm{~m}$ during the extrusion of the Main Eruptive Complex.

The lava delta located to the southeast of Tarrafal, possibly belonging to the Preguiça Formation, exhibits a submarine morphology whose passage zone can be presently seen no higher than $5 \mathrm{~m}$ asl. 


\subsubsection{The Monte Gordo Formation}

The Monte Gordo Formation correspond to the majority of the well preserved cones in São Nicolau, and associated products. Because many of the products and morphologies of the Preguiça Formation are still well preserved, it is very difficult to distinguish them from the younger Monte Gordo Formation. Thus, with a few exceptions, the separation between these units based only in a geomorphological character is somewhat artificial. Notwithstanding, none of the structures attributed to the Monte Gordo Formation seems to exhibit clear submarine morphologies.

\subsubsection{Quaternary sediments and wave-cut surfaces}

A close look at the coastal morphology of São Nicolau reveals the presence of large exposed recent marine abrasion surface(s) up to 50-60 m asl, partially covered by later volcanism and alluvial fan deposits. We shall describe a few areas where these features are well observed.

In the stretch of coast running between Praia Branca and Tarrafal, a flat morphology can be found from the present coastline up to $1.5 \mathrm{~km}$ inland. This platform is comprehended between the present sea-level and 50-60 m asl, running against the old backbeach cliff. Between Praia Branca and Barril, the platform is covered by two recent strombolian cones and associated products, probably belonging to the Monte Gordo Formation. Between Barril and Tarrafal, the platform is covered in extensive alluvial fan deposits.

In Ponta da Vermelharia, the platform occurs very regularly up to $200 \mathrm{~m}$ inland and up to 20 $\mathrm{m}$ asl. Further north and towards Turil, the platform widens up to $1 \mathrm{~km}$ inland and is extensively covered in alluvial fan deposit. However, scattered outcrops of fossiliferous calcarenites can be found up to $30 \mathrm{~m}$ asl.

Along the coast between Morre Brás and Ponta Chã de Norte, the platform is also very wide and several outcrops of fossiliferous calcarenites can be found at 20-30, $10 \mathrm{~m}$ and 5-7 m asl. The deposits in Coelha region (20-30 m asl) deserve a special mention due to quality of their 


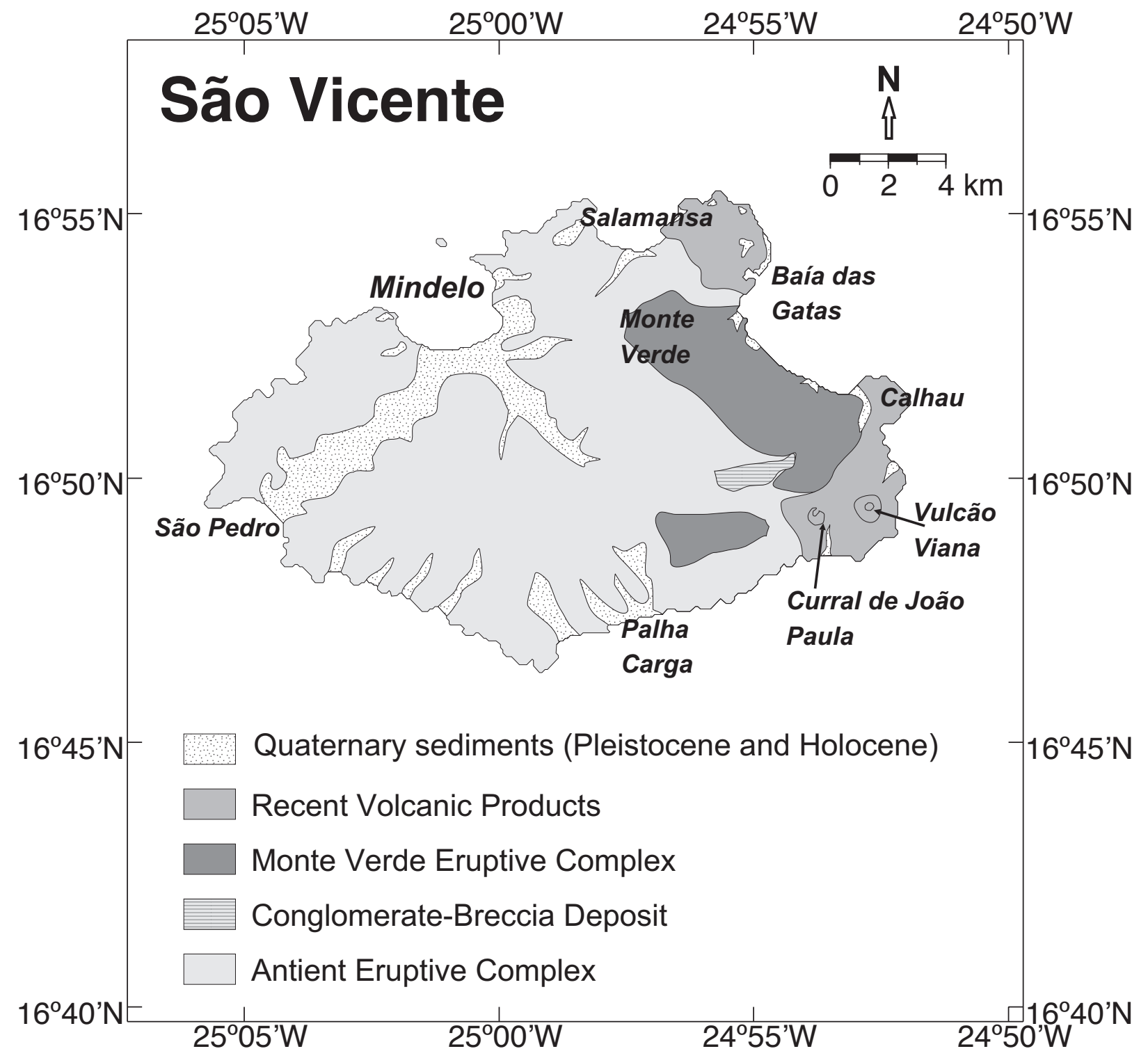

Figure S7: Geological map of São Vicente, based on the volcanostratigraphy defined by Serralheiro et al. (1974) and Jørgensen \& Holm (2002). 
fossil preservation and because they are covered by pyroclasts of the Monte Gordo Formation (Macedo et al. 1988). These sediments comprise conglomerates with calcarenite matrix, not exceeding a total thickness of $2 \mathrm{~m}$, and their fossil association includes large oysters, other bivalves, gastropods, corals, bryozoa and very well preserved worm-burrows.

The platform is also evident along the coast stretching from Juncalinho and Rocha Esforcado, where a palaeo coast line, defined at he base of the backbeach cliff, is very evident at 30 $\mathrm{m}$ asl.

\subsection{São Vicente}

São Vicente's volcanostratigraphy was defined by Serralheiro (1976) and comprises: Ancient Eruptive Complex; Conglomerate-Breccia Deposit; Monte Verde Eruptive Complex; Recent Volcanic products; and Quaternary Sedimentary Formations (see Figure S7, and Table 6 in the main text).

The only markers of past sea-level found in São Vicente seem to be restricted to a few Quaternary terraces located in São Pedro, Salamansa-Baia das Gatas, and Curral de João Paula areas.

The marine sediments near São Pedro crop out $1 \mathrm{~km}$ to NE of the village, at $\sim 18 \mathrm{~m}$ asl. These are conglomerates to micro-conglomerate beds, comprising terrigenous pebbles in a calcarenitic matrix, up to $1 \mathrm{~m}$ of total thickness (normally less). Abundant bivalves and gastropods can be found. The deposit indicates a shallow marine/beach depositional environment that marks a palaeo-shore.

Around the coast of Salamansa/Baia das Gatas, at 2-4 m asl, there is a raised beach deposit atop the young lavas that constitute this peninsula. They form a discontinuous belt parallel to the coastline and comprise very fossiliferous bivalve- and gastropod-rich calcarenites, probably formed during the last highstand.

Finally, in Ribeira de João Paula, on top of the young flows originated in the Vulcão Viana 


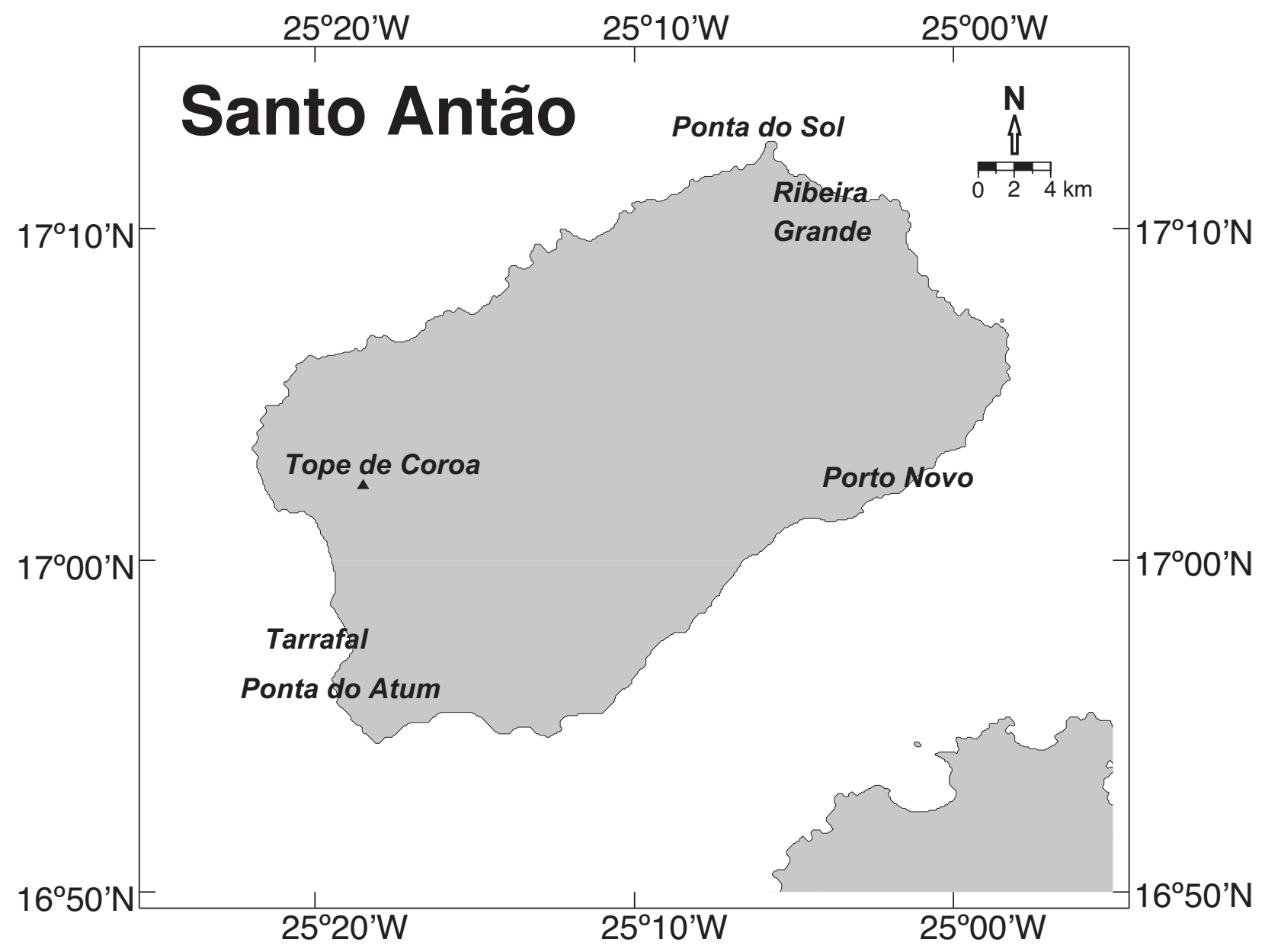

Figure S8: Location map of Santo Antão. 
and the Curral de João Paula cones, a calcarenite to micro-conglomerate deposit crops out in the riverbed $12 \mathrm{~m}$ asl and is up to $70 \mathrm{~cm}$ thick. The base of the deposit is micro-conglomeratic, rich in volcaniclastic material and shell debris, and at the top grades to a calcarenite with frequent oysters and other bivalves, gastropods, and corals. The deposit is extensively covered by an alluvial fan deposit and is only visible in the riverbed where washouts clear the recent cover. The macro-fauna indicates deposition in a shallow marine environment, suggesting a contemporaneous sea-level height of $\sim 15 \mathrm{~m}$ asl. A minimum age of $\sim 0.3 \mathrm{Ma}$ is inferred, because this age is attributed to the lavas that underlie the deposit. Similar deposits are reported by Bebiano (1932) in Palha Carga valley.

\subsection{Santo Antão}

The only solid palaeo-markers of sea-level found in Santo Antão occur in Ponta do Atum and in Ponta do Sol (see Figure S8).

The Ponta do Atum sequence constitutes a solid tracer of sea-level, but its young age only pinpoints a few Quaternary sea-level positions (see Figure S9). The sequence is exposed along $<1 \mathrm{~km}$ in the southern part of Tarrafal bay, and comprises from the base to the top: older subaerial lavas; coastal sediments; younger subaerial lavas that grade laterally to submarine (at lower elevations); Pleistocene beach deposits; Holocene beach deposits. The older subaerial lavas are of unknown age and form a sequence of southwest dipping flows in which an abrasion surface and cliff were carved. This surface subsequently filled by $>40 \mathrm{~m}$ of coastal sediments comprising terrigenous conglomerates and sands, with fossiliferous calcarenites at the base. The conglomerates exhibit poorly sorted rounded clasts, in a sandy matrix. This sedimentary sequence seems to correspond to a coastal fan-delta deposit, as suggested by the transition from a shallow marine/beach-type facies to a more debris-flow facies. The sediments were then covered by lavas that flowed from the NE, probably from one of the many vents located in the plateau above. The lavas flowed over the sediments, baking the topmost layer, and passed 


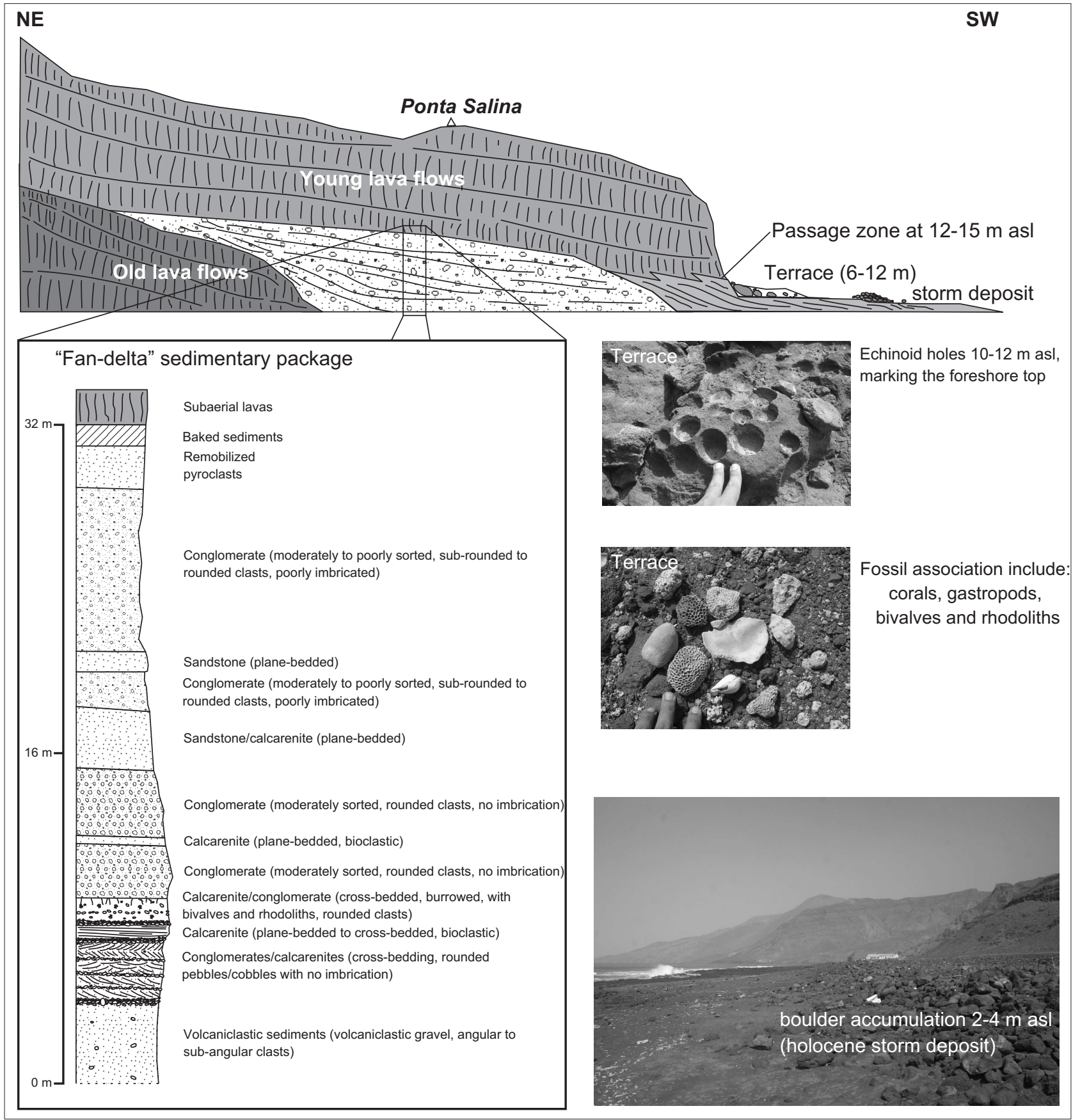

Figure S9: Schematic cross section of Ponta do Atum (Santo Antão), and details. 
laterally into pillow-lavas and submarine sheet flows when they entered the sea. The passage zone is irregular and difficult to detect but seems to be presently at 12-15 m, or possibly a few meters higher, suggesting a contemporaneous relative sea-level at this elevation. The young lavas probably correspond to the Young Tarrafal volcanic unit identified by Holm et al. (2006), which erupted between 0.4 and 0.2 Ma. The whole sequence was again eroded more recently, leading to the creation of a marine abrasion surface presently between 6 and $12 \mathrm{~m}$. This surface exhibits scattered coarse calcarenites with well preserved corals, gastropods, oysters and other bivalves (in the palaeo shoreface), and the contemporaneous foreshore is marked by the presence of well preserved echinoderm holes dug in the volcanic bedrock. A linear accumulation of beach boulders, parallel to the coastline and interpreted as Holocene storm deposits, marks the top of the present day foreshore.

The Ponta do Sol carbonate sediments are thin $(20-30 \mathrm{~cm})$ calcarenites, with abundant bivalves and gastropods, revealing a shallow marine origin, deposited over conglomerates and covered by debris flow deposits. Presently this terrace is reduced to a few small outcrops at 15 $\mathrm{m}$ asl.

\section{References}

Bebiano, J. 1932. A geologia do arquipélago de Cabo Verde, Comunicações dos Serviços Geológicos de Portugal, (18), 167-187.

Berggren, W., Kent, D. \& Aubry, M.-P. 1995. A revised cenozoic geochronology and chronostratigraphy, SEPM Special Publication, 54, 129-212.

Bernoulli, D., Hottinger, L., Spezzaferri, S. \& Stille, P. 2007. Miocene shallow-water limestones from São Nicolau (Cabo Verde): Caribbean-type benthic fauna and time constraints for volcanism, Swiss Journal of Geosciences, 100(2), 215-225. 
Bosence, D. 1983. Coralline algar reef frameworks, J. Geol. Soc. London, 140, 365-376.

Davies, G., Norry, M., Gerlach, D. \& Cliff, R. 1989. A combined chemical and Pb-Sr-Nd isotope study of the Azores and Cape Verde hot spots; the geodynamic implications, Geological Society, London, Special Publications, 42(1), 231-255.

Duprat, H., Friis, J., Holm, P., Grandvuinet, T. \& Sørensen, R. 2007. The volcanic and geochemical development of São Nicolau, Cape Verde Islands: Constraints from field and 40Ar/39Ar evidence, Journal of Volcanology and Geothermal Research, 162(1-2), 1 - 19.

Gerlach, D., Cliff, R., Davies, G., Norry, M. \& Hodgson, N. 1988. Magma sources of the Cape Verde Archipelago: Isotopic and trace element constraints, Geochimica et Cosmochimica Acta, (52), 2979-2992.

Holm, P., Wilson, J. R., Christensen, B., Hansen, L., Hansen, S., Khein, K. M., Mortensen, A., Pedersen, R., Plesner, S. \& Runge, M. 2006. Sampling the Cape Verde Plume: Evolution of Melt Compositions on Santo Antão, Cape Verde Islands, Journal of Petrology, 47(1), $145-189$.

Holm, P., Grandvuinet, T., Friis, J., Wilson, J. R., Barker, A. K. \& Plesner, S. 2008. An 40Ar-39Ar study of the Cape Verde hot spot: Temporal evolution in a semistationary plate environment, J. Geophys. Res., 113.

Jørgensen, J. \& Holm, P. 2002. Temporal variation and carbonatite contamination in primitive ocean island volcanics from São Vicente, Cape Verde Islands, Chemical Geology, 192(3-4), 249-267.

Lecointre, G. 1963. Sur les terrains sedimentaires de l'île du Sal, Garcia de Orta, Serviços Geológicos, 11(2), 275-289. 
Macedo, J., Serralheiro, A. \& Silva, L. 1988. Notícia Explicativa da Carta Geológica da Ilha de S. Nicolau (Cabo Verde) na escala de 1:50000, Garcia de Orta, Serviços Geológicos, 11(1-2), $1-32$.

Mitchell, J., Bas, M. L., Zielonka, J. \& Furnes, H. 1983. On dating the magmatism of Maio, Cape Verde Islands, Earth and Planetary Science Letters, 64(1), 61 - 76.

Ogg, J., Ogg, G. \& Gradstein, F. 2008. The concise geologic time scale, The Concise Geologic Time Scale, by JG Ogg, G. Ogg, and FM Gradstein. Cambridge: Cambridge University Press. ISBN: 9780521898492..

Serralheiro, A. 1968. Formações Sedimentares do Arquipélago de Cabo Verde, Junta de Investigações do Ultramar.

Serralheiro, A. 1970. Geologia da Ilha de Maio (Cabo Verde), Junta de Investigações do Ultramar.

Serralheiro, A. 1976. A Geologia da Ilha de Santiago (Cabo Verde), Boletim do Museu e Laboratorio Mineralógico e Geológico da Faculdade de Ciências, 14, 157-369.

Serralheiro, A. \& Ubaldo, M. 1979. Estudo estratigráfico dos sedimentos do Campo da Preguiça ilha de S. Nicolau (Cabo Verde), Garcia de Orta, Serviços Geológicos, 3(1-2), 75-82.

Serralheiro, A., Alves, C., Macedo, J. \& Silva, L. 1974. Note preliminaire sur la géologie de l'île de Boa Vista (Cap-Vert), Garcia de Orta, Serviços Geológicos, 1(3), 53-60.

Silva, L., Le Bas, M. \& Robertson, A. 1981. An oceanic carbonatite volcano on Santiago, Cape Verde Islands, Nature, 294, $644-645$.

Silva, L., Serralheiro, A., Macedo, J., Gomes, A. \& Torres, P. 1990. Carta Geológica de Cabo Verde, Ilha do Sal, na escala de 1/25000 (folhas 1-2), Edição do Instituto Investigação Científica Tropical/Instituto de Cooperação Económica. 
Stillman, C., Furnes, H., Le Bas, M., Robertson, A. \& Zielonka, J. 1982. The geological history of Maio, Cape Verde Islands, J. Geol. Soc. London, 139, 347-361.

Torres, A. \& Soares, J. 1946. Formações Sedimentares do Arquipélago de Cabo Verde. I Actualização de conhecimentos, in Memórias dos Serviços Geológicos, p. 398, Junta das Missões Geográficas e de Investigações Coloniais.

Torres, P., Silva, L., Serralheiro, A., Mendes, M., Macedo, J. \& Gomes, A. 2002. Geologia da Ilha do Sal, Comunicações do Instituto de Investigação Científica Tropical.

Torres, P., Silva, L., Serralheiro, A., Tassinari, C. \& Munhá, J. 2002. Enquadramento geocronológico pelo método K/Ar das principais sequências vulcano-estratigráficas da Ilha do Sal - Cabo Verde, Garcia de Orta, Serviços Geológicos, 18(1-2), 9-13.

Ubaldo, M., Silva, L. \& Torres, P. 1991. Contribuição geológica e micropaleontologica para o conhecimento do "Complexo Eruptivo Antigo" da ilha do Sal, Arquipélago de Cabo Verde, Garcia de Orta, Serviços Geológicos, 14(1-2), 9-14.

Webster, J., Clague, D., Braga, J., Spalding, H., Renema, W., Kelley, C., Applegate, B., Smith, J., Paull, C., Moore, J. \& Potts, D. 2006. Drowned coralline algal dominated deposits off Lanai, Hawaii; carbonate accretion and vertical tectonics over the last 30 ka, Marine Geology, 225(1-4), $223-246$.

Zazo, C., Goy, J., Dabrio, C., Soler, V., Hillaire-Marcel, C., Ghaleb, B., González-Delgado, J., Bardají, T. \& Cabero, A. 2007. Quaternary marine terraces on Sal Island (Cape Verde archipelago), Quaternary Science Reviews, 26(7-8), 876 - 893. 